\title{
Mechanical and Adsorptive Properties of Foamed EVA-Modified Polypropylene/Bamboo Charcoal Composites
}

\author{
Wenzhu Li ${ }^{1}$, Jing Zhang ${ }^{1}$, Jingda Huang ${ }^{1, *}$, Yuanchao Shao ${ }^{1}$, Wenbiao Zhang ${ }^{1, *}$ and Chunping Dai ${ }^{2}$ \\ 1 School of Engineering, Zhejiang A\&F University, Hangzhou 311300, China; lwz@zafu.edu.cn (W.L.); \\ zj12345662020@163.com (J.Z.); Shao19981211@163.com (Y.S.) \\ 2 Department of Wood Science, Faculty of Forestry, University of British Columbia, 2900-2424 Main Mall, \\ Vancouver, BC V6T 1Z4, Canada; chunping.dai@ubc.ca \\ * Correspondence: hjd1015@163.com (J.H.); zwb@zafu.edu.cn (W.Z.)
}

check for updates

Citation: Li, W.; Zhang, J.; Huang, J.; Shao, Y.; Zhang, W.; Dai, C.

Mechanical and Adsorptive Properties of Foamed EVA-Modified Polypropylene/Bamboo Charcoal Composites. Materials 2021, 14, 1524. https://doi.org/10.3390/ma14061524

Academic Editor: Tomasz Sadowski

Received: 17 February 2021

Accepted: 18 March 2021

Published: 20 March 2021

Publisher's Note: MDPI stays neutral with regard to jurisdictional claims in published maps and institutional affiliations.

Copyright: (C) 2021 by the authors. Licensee MDPI, Basel, Switzerland. This article is an open access article distributed under the terms and conditions of the Creative Commons Attribution (CC BY) license (https:/ / creativecommons.org/licenses/by/ $4.0 /)$.

\begin{abstract}
Due to its excellent adsorption and humidity control function, bamboo charcoal (BC) has often been mixed with polypropylene (PP) to produce PP/BC composites for interior paneling applications. However, due to the poor foaming quality of $\mathrm{PP}, \mathrm{PP} / \mathrm{BC}$ composites suffer as a result of their high density, which limits their scope of use. Here, to improve its foaming quality, PP was modified with ethylene vinyl acetate (EVA), and then the EVA-modified PP (E-PP) was mixed with different contents of BC ( $0 \mathrm{wt} . \%-50 \mathrm{wt} . \%)$, as well as foaming agent (Azodicarbonamide, AC) and its auxiliaries ( $\mathrm{ZnO}, \mathrm{Znst})$, in a twin-screw extruder, followed by hot-pressing at high temperature to obtain foamed E-PP/BC composites. The resulting composites showed good porosity and pore distribution with an increase of BC content by up to $20 \%$. Further increase in the BC content seemed to cause the foaming performance to decrease significantly. The product density and adsorption rate increased, while the mechanical strength decreased with increasing BC content. At a BC content of $40 \mathrm{wt} . \%$, the foamed E-PP/BC composite showed the best combined performance, with a density of $0.90 \mathrm{~g} / \mathrm{cm}^{3}, 24-\mathrm{h}$ formaldehyde adsorption rate of 0.48 , and bending strength of $11.59 \mathrm{MPa}$.
\end{abstract}

Keywords: bamboo charcoal; polypropylene; ethylene vinyl acetate; formaldehyde; foamed composite

\section{Introduction}

Plastic materials have been developed and used widely for more than one hundred years because of their good processing property, chemical stability, electrical insulation, and impact resistance [1-3]. For the foreseeable future, plastics will remain an indispensable industrial material [4], despite their pollution problems [5,6]. In the meantime, efforts have been made to recycle plastics like metal materials $[7,8]$, or to mix them with other fillers to reduce the white pollution $[9,10]$.

Polypropylene (PP), as a common and low-density (only $0.89-0.91 \mathrm{~g} / \mathrm{cm}^{3}$ ) plastic, has been well studied in terms of its substitution by more environmentally friendly fillers in order to achieve improvements in impact and aging resistance [11-13]. Studies have also been conducted to reduce PP density by foaming [14] and improving the properties of oil absorption and electric conduction $[15,16]$. However, PP is not as easy to foam as other plastics, such as polyurethane (PU), polystyrene (PS), and polyvinylchloride (PVC) [17]. Due to the inherent fluidity of PP, when the temperature exceeds its melting point, the melt viscosity drops rapidly. As a result, PP's foaming temperature range is relatively narrow, close to its crystallization point [18-20].

Plastic-based composites have also been investigated as a way to reduce plastic usage and introduce new functions [21,22]. For example, wood-plastic composites [23] possess the durability of plastic and the biomass performance of wood; plastic-rubber composites [24] improve the rigidity of plastic; plastic-carbon fiber composites [25] modify the brittleness of plastic. Bamboo charcoal (BC) is a pyrolysis of solids from bamboo or bamboo residues with a highly porous structure that is suited for a wide variety of 
applications, including water purification, architectural decoration, daily chemicals, and the food industry [26,27]. BC is especially suited for the removal of formaldehyde, which is commonly found in interior wood composites [28-31]. It is an emerging green industrial material and is playing an important role in the development of the low-carbon and circular economy. BC/PP composites [32] have been the focus of research in recent years. For example, Zhang et al. $[33,34]$ used BC particles with different sizes and bamboo powder to modify PP by melt blending. It was shown that $\mathrm{BC}$ particles of suitable size were able to greatly enhance the mechanical and other material properties of $\mathrm{PP} / \mathrm{BC}$ composites.

While BC/PP composites exhibit multifunctional properties, most of the studies to date have only focused on the effect of a small amount of $\mathrm{BC}$ on the modification of PP. In addition, little work has been reported on reducing the density of $\mathrm{BC} / \mathrm{PP}$ composites through foaming. This study aims to further investigate BC/PP composites with the goal of improving their foaming performance and reducing the usage of PP. Ethylene vinyl acetate (EVA) was first used as a foaming modifier for PP. Then, the EVA-modified PP (E-PP) was mixed with BC and foaming agent and other additives. Subsequently, the foamed E-PP/BC composites were prepared using hot-pressing, and the adsorption and mechanical properties were finally evaluated and discussed.

\section{Results and Discussion}

\subsection{Formation Mechanism of Foamed E-PP/BC Composites}

The reason for choosing EVA as a modifier is that EVA is a low-cost and low-density elastomer that can facilitate micro-foaming in the PP matrix. EVA has a high melting point and is able to increase the melt strength of PP, while being conducive to evenly dispersing the gas and to locking the bubbles during the foaming process. In our previous study, the foaming properties of PP and E-PP were compared. The results indicated that the foamed PP had nonuniform and large-sized bubble pores, while the foamed E-PP exhibited more uniform and smaller-sized bubble pores at 5\% of EVA [35]. As shown in Figure 1, first, PP was modified by EVA to obtain E-PP. Then, to facilitate dispersion, the additives, comprising $\mathrm{AC}$ (foaming agent), $\mathrm{ZnO}$, and $\mathrm{Znst}$, were mixed with E-PP and made into the E-PP/auxiliaries masterbatch using a twin-screw extruder. Subsequently, the BC and $\mathrm{E}-\mathrm{PP} /$ auxiliaries masterbatches were melt blended to prepare the E-PP/BC/auxiliaries masterbatch, followed by hot-pressing. At this moment, $\mathrm{AC}$ was decomposed into masses of nitrogen $\left(\mathrm{N}_{2}\right)$ and $\mathrm{CO}$ under high temperatures, and both $\mathrm{ZnO}$ and Znst played a role in accelerating thermal decomposition. This is because the $\mathrm{N}-\mathrm{C}$, which has a lower bond energy than $\mathrm{N}=\mathrm{N}$, is easier to break in order to generate acylamino $\left(2 \mathrm{H}_{2} \mathrm{~N}-\mathrm{C} \cdot\right)$ and $\mathrm{N}_{2}$, and then the generated acylaminos react with each other, generating $\mathrm{CO}$ and urea. The $\mathrm{N}_{2}$ and $\mathrm{CO}$ are able to cause the matrix to produce pores, thus resulting in the foamed E-PP/BC composite [36]. 


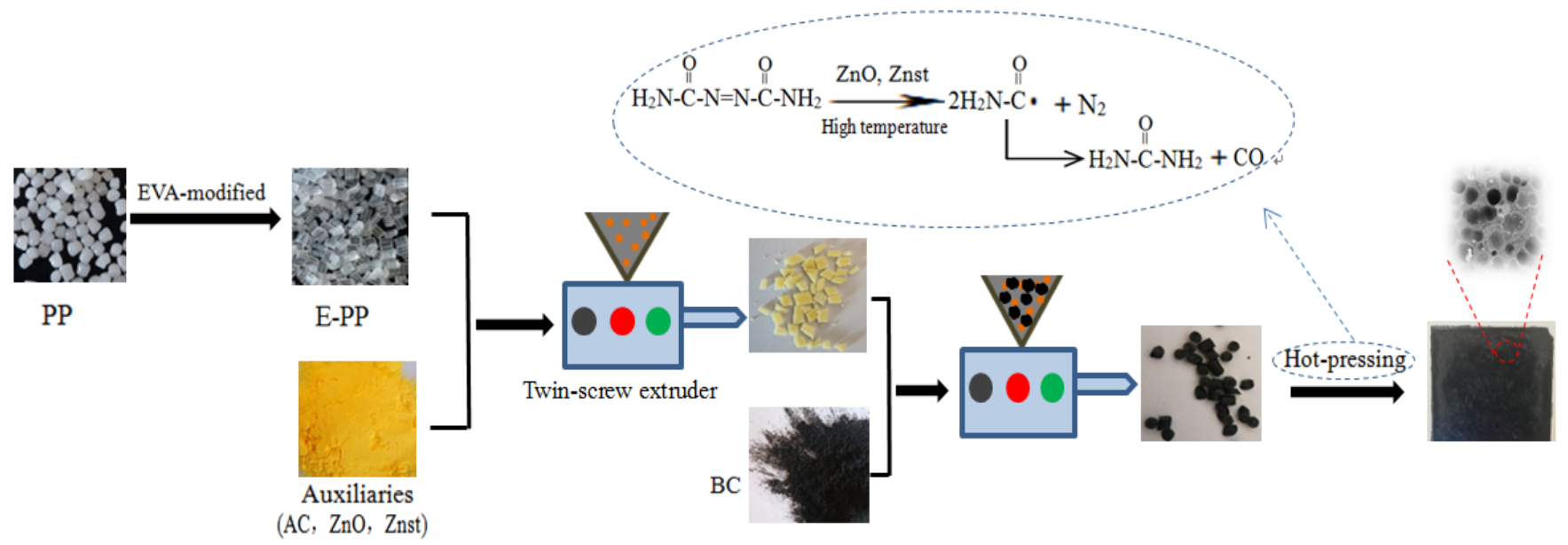

Figure 1. Preparation process and forming mechanism of the foamed E-PP/BC composites.

\subsection{Surface Morphologies}

SEM images of the foamed E-PP/BC composites with different BC content are shown in Figure 2. The pure foamed E-PP shows amounts of closed pores and some parallel and capacitive pores (Figure 2a). At a small amount of added BC (5 wt.\%), the foaming effect is not very different, but the parallel and capacitive pores are reduced (Figure $2 \mathrm{~b}$ ). The results of the mercury injection test are shown in Figure 3. The foamed E-PP/BC (5 wt.\%) composite shows an average pore size of about $44.64 \mu \mathrm{m}$ and a porosity of $24.27 \%$. At an amount of added BC of $20 \mathrm{wt}$ \%, the pores of the foamed composite become irregular (Figure 2c), which might be caused by the difficulty of gas encapsulation due to the melt fluidity of E-PP being reduced with the increase of BC. At this time, its average pore size and porosity is improved to about $34.35 \mu \mathrm{m}$ and $28.24 \%$, respectively. At amounts of added BC of $30 \mathrm{wt} . \%$ and $40 \mathrm{wt} . \%$, the foamed composites show the same irregular pore shape and smaller (10 to $28 \mu \mathrm{m}$ ) pore size (Figure $2 \mathrm{~d}$,e). As can be seen from the high magnification image in Figure 2e, BC particles were mostly encased, and appeared be poorly bonded by E-PP, resulting in lower mechanical strength. At an added BC amount of $50 \mathrm{wt} . \%$, the pore size and shape of the foamed composite were very uneven, showing poor foaming quality (Figure 2f), resulting from the large amount of BC blocking the flow of E-PP. As such, the average pore size increased to $67 \mu \mathrm{m}$, and the porosity decreased to $20.16 \%$ (Figure 3 ). Overall, the foaming quality of the composites seemed to suffer the least with up to $20 \%$ addition of $\mathrm{BC}$. 

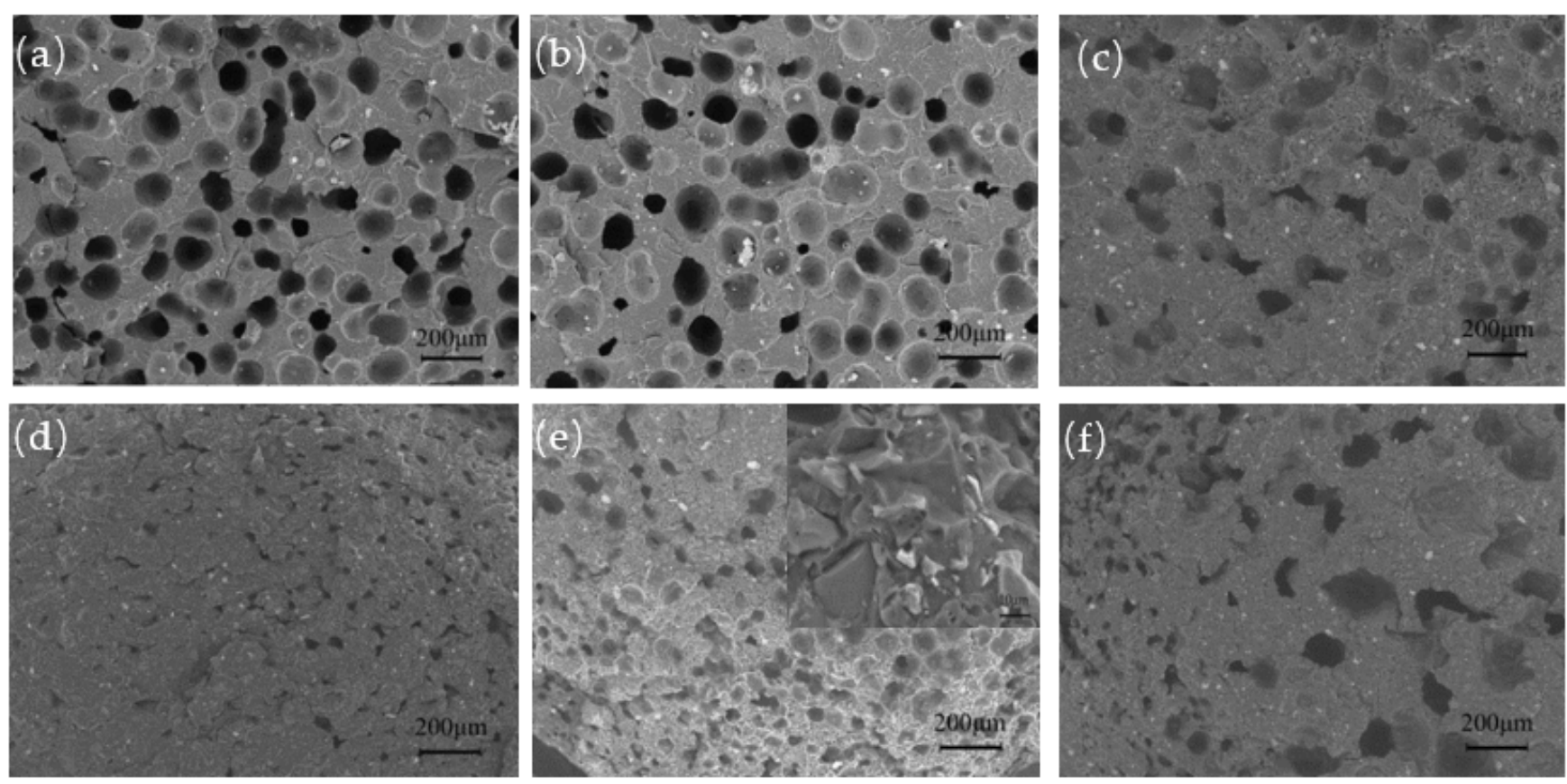

Figure 2. SEM images of the foamed E-PP/BC composites with BC content of (a) 0 wt. \%, (b) 5 wt. \%, (c) 20 wt. \%, (d) 30 wt. $\%$, (e) $40 \mathrm{wt} . \%$, and (f) $50 \mathrm{wt.} \%$.

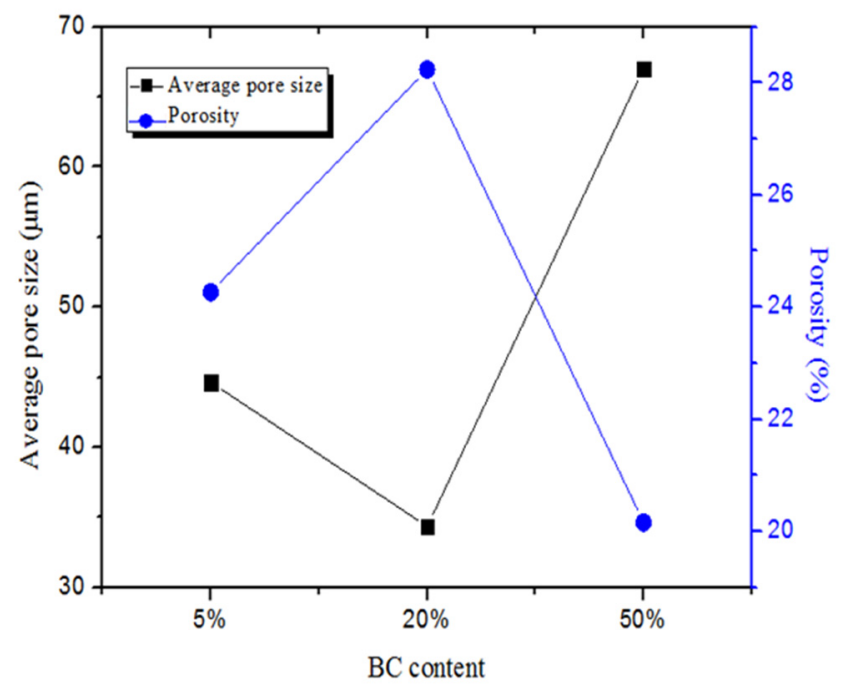

Figure 3. The average pore size and the porosity of the foamed E-PP/BC composites with different BC content.

\subsection{Chemical Component Analysis}

To verify the combination mode between $\mathrm{BC}$ and E-PP in the composite, $\mathrm{BC}, \mathrm{E}-\mathrm{PP}$, and their composite were analyzed by FTIR. As shown in Figure 4, the absorption peaks of $\mathrm{BC}$ are mainly at $3455 \mathrm{~cm}^{-1}(-\mathrm{OH}), 1590 \mathrm{~cm}^{-1}(\mathrm{C}=\mathrm{C})$, and $1078 \mathrm{~cm}^{-1}(\mathrm{C}-\mathrm{O})$. In addition, the absorption peaks of E-PP are mainly at $2953 \mathrm{~cm}^{-1}, 2845 \mathrm{~cm}^{-1}, 1459 \mathrm{~cm}^{-1}, 1377 \mathrm{~cm}^{-1}$, $1156 \mathrm{~cm}^{-1}, 1156 \mathrm{~cm}^{-1}$, and $971 \mathrm{~cm}^{-1}$, and are generated by the symmetric and asymmetric stretching vibrations of $-\mathrm{CH}_{3}$ and $-\mathrm{CH}_{2}$. However, the foamed E-PP/BC composite does not show new absorption peaks that are different from those of $\mathrm{BC}$ and E-PP. Therefore, the combination of BC and PP should be physical. 


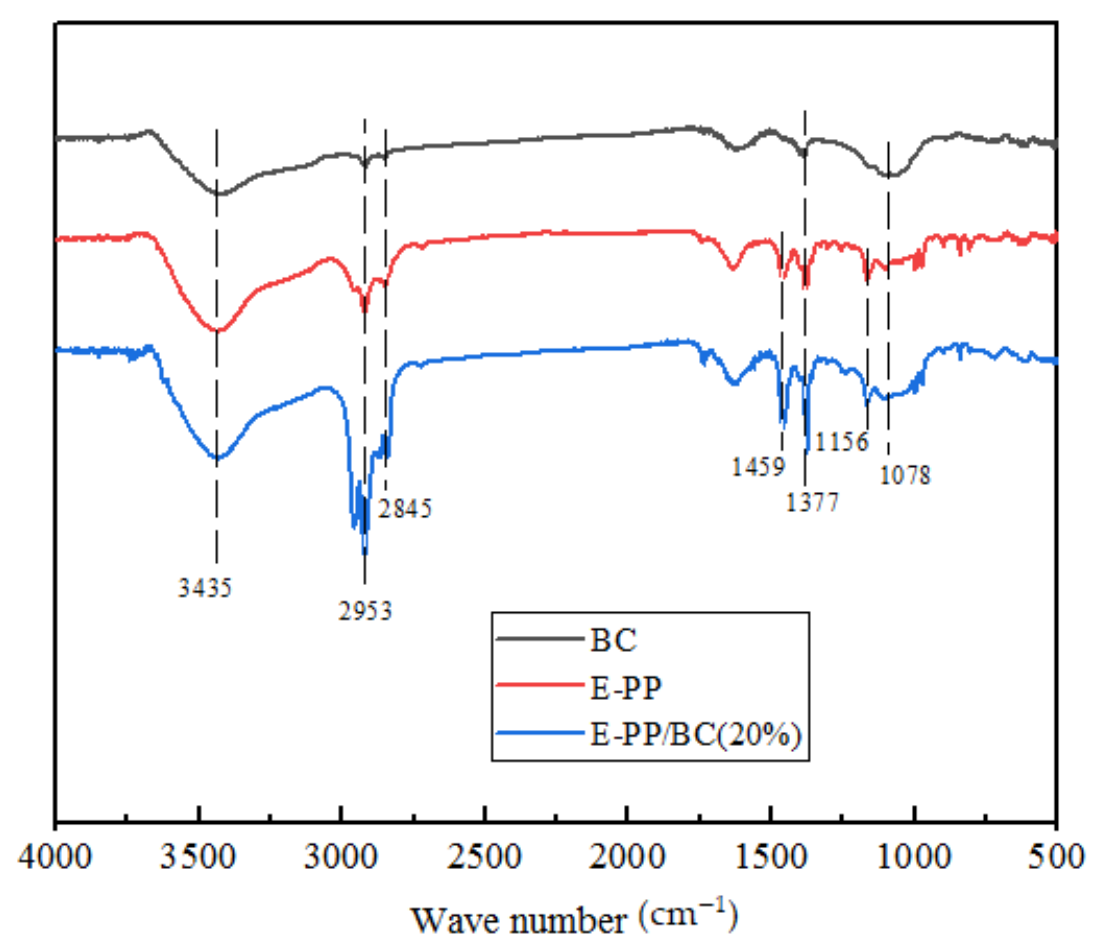

Figure 4. FTIR spectra of BC, E-PP, and the E-PP/BC (20 wt.\%) composite.

To check the change of the crystal structure during the preparation process, XRD was analyzed, as shown in Figure 5. BC has two relatively obvious diffraction peaks near $24^{\circ}$ and $43^{\circ}$, corresponding to the characteristic diffraction peaks of graphite microcrystalline (001) and (002), respectively, thus confirming that BC is an amorphous carbon structure based on a graphite-like microcrystalline structure, because PP is a substance that is easy to crystallize, and E-PP shows diffraction peaks near $14^{\circ}, 17^{\circ}$, and $19^{\circ}$, which correspond to the $\alpha$-crystal PP(110), (040), and (130) planes, respectively. Compared with BC and E-PP, there are no more diffraction peaks in the foamed E-PP/BC composites, thus indicating that their crystal phase does not undergo a change during the preparation process. However, the diffraction peaks become weaker with increasing content of $\mathrm{BC}$. This may be due to the fact that $\mathrm{BC}$ as a filler restricts the movement of E-PP molecular chain, thus reducing the interface free energy required for crystallization nucleation.

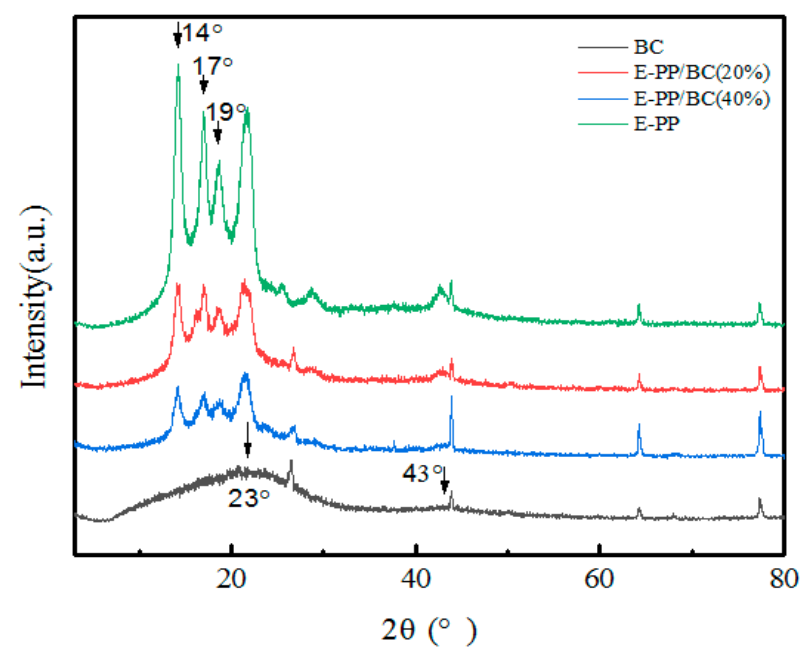

Figure 5. XRD patterns of BC, E-PP, and foamed E-PP/BC (20 wt. \% and $40 \mathrm{wt} . \%)$ composites. 


\subsection{Density of Foamed E-PP/BC Composites}

The change of the density of the foamed composites with different $\mathrm{BC}$ content is shown in Figure 6. The density of the pure foamed E-PP was $0.67 \mathrm{~g} / \mathrm{cm}^{3}$. In addition, the density is enhanced with increasing $\mathrm{BC}$ content in the foamed composites. Compared with the composite without $\mathrm{BC}$, the density of the composite ( $5 \mathrm{wt} . \%)$ was only increased to $0.68 \mathrm{~g} / \mathrm{cm}^{3}$, and the pore size and distribution were not significantly effected (as shown in Figure $2 \mathrm{a}, \mathrm{b}$ ). In contrast, a small amount of BC was able to act as a heterogeneous nucleation agent to provide effective nucleation sites for the foaming agent and to make the pores uniform, reducing the number of parallel and capacitive pores, as well as pore collapse. With increasing BC content, the density of the composite continued to increase, reaching $0.90 \mathrm{~g} / \mathrm{cm}^{3}$ at a BC content of $40 \mathrm{wt} . \%$, and $0.99 \mathrm{~g} / \mathrm{cm}^{3}$ at a BC content of $50 \%$. This is because BC has a higher density (as shown in Section 3.1) than E-PP, and the effect of foaming is also affected by it.

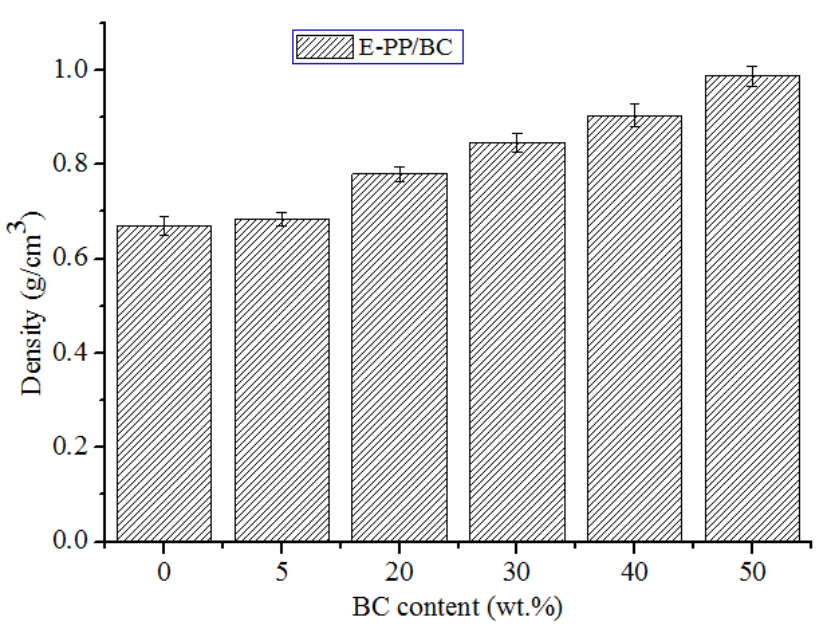

Figure 6. Change in the density of the foamed E-PP/BC composites with different BC content.

\subsection{Formaldehyde Adsorption Performance}

After bamboo pyrolysis, the tubular bundles and parenchyma cells became thinner and their cell cavities became larger, forming the porous structure of BC. On the basis of their different sizes, the pores of $\mathrm{BC}$ can generally be divided into three categories: macropores $(>50 \mathrm{~nm})$, mesopores $(20-50 \mathrm{~nm})$, and micropores $(<20 \mathrm{~nm})$, of which, the macropore and mesopores are predominant [37]. The abundance of pores causes the excellent adsorption ability, and this is often used to adsorb harmful gases such as benzene and formaldehyde in indoor air. The test for formaldehyde adsorption is shown in Figure 7a; samples with a size of $10 \mathrm{~mm} \times 10 \mathrm{~mm} \times 4 \mathrm{~mm}$ were put into a formaldehyde adsorption testing desiccator at $26 \pm 2{ }^{\circ} \mathrm{C}$ for $24 \mathrm{~h}$. Figure $7 \mathrm{~b}$ shows the relationship between the foamed E-PP/BC composites and the formaldehyde adsorption rate. When the amount of $\mathrm{BC}$ added was less than $5 \mathrm{wt} . \%$, the composites showed no formaldehyde adsorption ability, because it is easy for a small amount of $\mathrm{BC}$ to be completely wrapped by E-PP without the pores being exposed. With increasing $\mathrm{BC}$ content, the formaldehyde adsorption rate exhibits a proportional improvement, with the formaldehyde adsorption rate being 0.48 when the amount of BC added was $40 \mathrm{wt} . \%$, and ranging up to 0.6 when the BC content was $50 \mathrm{wt} . \%$. This is because, with increasing $B C$ content, some part of the $B C$ is not covered, leading to a certain adsorption effect. 

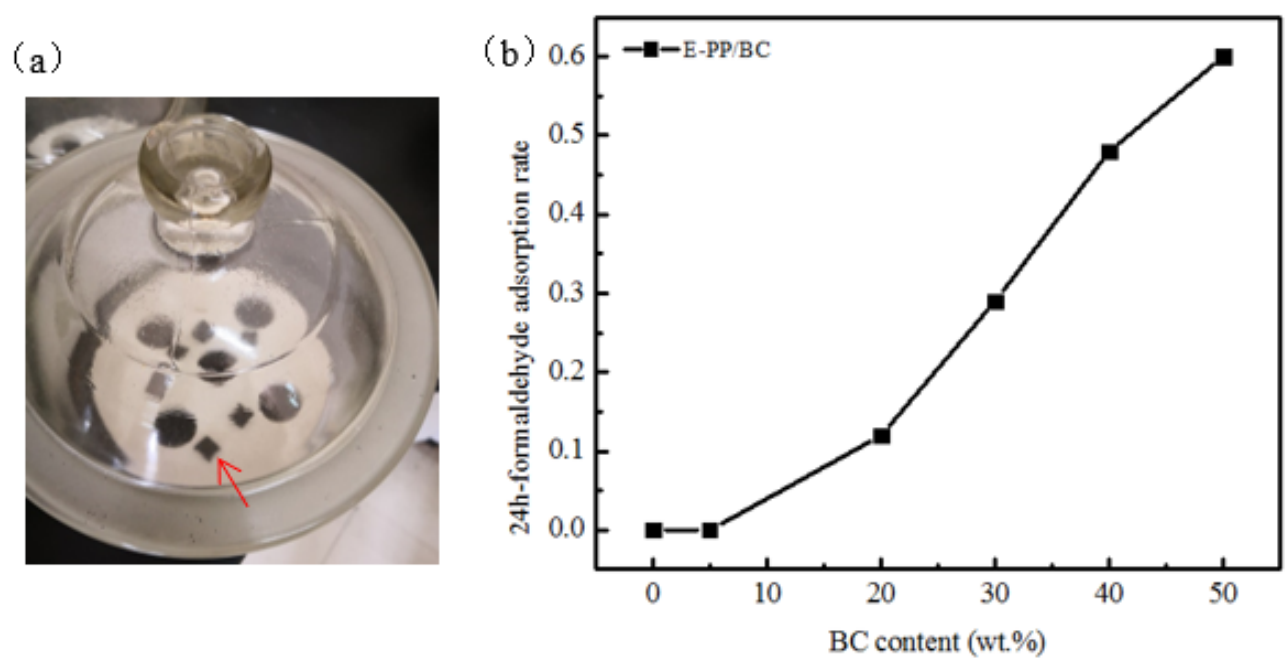

Figure 7. Formaldehyde adsorption testing and results: (a) formaldehyde adsorption testing desiccator, and (b) 24-h formaldehyde adsorption rate curves of the foamed E-PP/BC composites with different BC content.

\subsection{Mechanical Performance}

Static bending strength was tested using a microcomputer-controlled electronic universal testing machine (as shown in Figure 8a), and was generally used to study the ability of materials to bear external loading without failure and also to indirectly characterize the dispersion situation of the fillers in the matrix. As shown in Figure 8b, with increasing $\mathrm{BC}$ content, the bending strength of the foamed E-PP/BC composites first goes up and then goes down. At a BC additive amount of $5 \mathrm{wt} . \%$, the bending strength of the foamed composite reaches a maximum of $15.01 \mathrm{MPa}$, which is $1.6 \%$ higher than that of the pure foamed E-PP. This is because at low BC content, the E-PP matrix in the composites plays a leading role, and $\mathrm{BC}$ scatters within it, destroying the original single phase, leading to a mechanical interlock with E-PP, thus enhancing their mechanical properties. However, when the BC is increased continuously to a content of $20 \mathrm{wt} . \%-40 \mathrm{wt} . \%$, their bending strength is actually reduced, although not obviously, reaching $12.9 \mathrm{MPa}, 12.45 \mathrm{MPa}$, and $11.59 \mathrm{MPa}$, respectively. However, at a BC content of $50 \mathrm{wt} . \%$, the bending strength drops significantly to $8.85 \mathrm{MPa}$. This is because a large amount of $\mathrm{BC}$ causes the contact area between $\mathrm{E}-\mathrm{PP}$ and $\mathrm{BC}$ to decrease, leading to aggregation of $\mathrm{BC}$ particles with poor bonding. Moreover, the heterogeneous pores in the foamed E-PP/BC composite are also one of the reasons for poor bending strength. Overall, the foamed E-PP/BC (40 wt.\%) composite seems to be the optimal level, because its bending strength is not reduced to the same extent, and meets the Chinese GB/T 9431-2008 standard. In addition, at this level, the formaldehyde adsorption index remains high, being only slightly lower than that at a BC content of 50 wt.\%. 
(a)

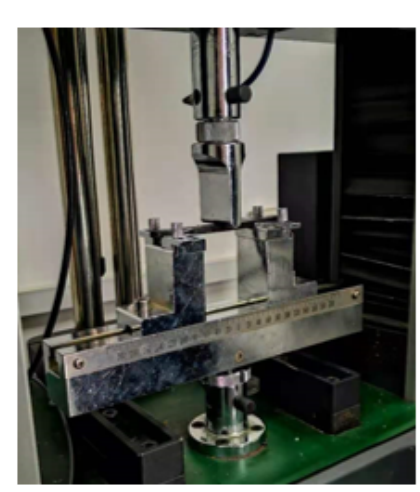

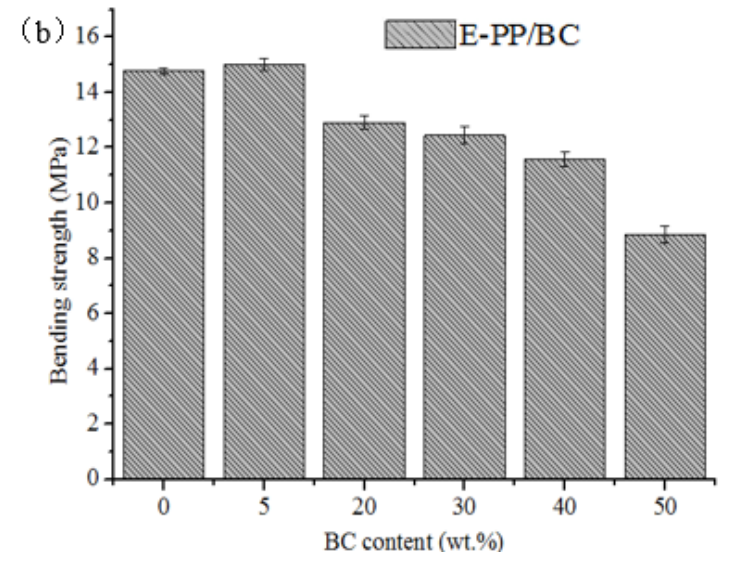

Figure 8. Mechanical testing and results: (a) picture of static mechanical performance testing and (b) bending strength of foamed E-PP/BC composites with different BC content.

\section{Materials and Methods}

\subsection{Materials}

Bamboo Charcoal (BC) particles (average diameter of $750 \mu \mathrm{m}$, density of $0.98-1.29 \mathrm{~g} / \mathrm{cm}^{3}$ ) were purchased from Jiangshan Lvyi Bamboo Charcoal Co., Ltd., Quzhou, Zhejiang, China; Polypropylene (PP, K8303), density of $0.89-0.91 \mathrm{~g} / \mathrm{cm}^{3}$ and melt flow rate of 1.0-3.0 g/10 min, was purchased from Suzhou aowigi new material Co., Ltd., Suzhou, China; Azodicarbonamide (AC, A.R.) as a foaming agent (foaming temperature of $195-210^{\circ} \mathrm{C}$ ), was purchased from Dongguan Haise Plastic Materials Co., Ltd.(Dongguan, Guangdong, China); $\mathrm{ZnO}$ and $\mathrm{Znst}$ as antioxidants were purchased from BASF AG (Ludwigshafen, Germany); Ethylene vinyl acetate (EVA, VA content of $18 \%, \mathrm{MI}=2.5)$, as a modifier, was purchased from Macklin Inc. (Pudong, Shanghai, China). All chemicals were used directly without further modification.

\subsection{EVA-Modified PP (E-PP)}

According to the mass ratio of 95:5, $\mathrm{PP}$ and EVA were mixed in the torque rheometer for $10 \mathrm{~min}$ at a temperature of $175^{\circ} \mathrm{C}$ and a speed of $55 \mathrm{r} / \mathrm{min}$. Subsequently, AC, $\mathrm{ZnO}$, and Znst were added to the above PP/EVA mixture, where their mass was $1.5 \mathrm{wt} . \%, 0.7 \mathrm{wt} . \%$, and $0.3 \mathrm{wt} . \%$, respectively, followed by being kept blending for $5 \mathrm{~min}$ and then drying; after this, the EVA-modified PP (E-PP) was obtained.

\subsection{Preparation of Foamed E-PP/BC Composites}

The foamed E-PP/BC composites were prepared using E-PP as a matrix and BC as fillers. To prepare the E-PP masterbatch well, E-PP was first mixed with foaming agent (AC) and its auxiliaries ( $\mathrm{ZnO}$ and $\mathrm{Znst}$ ) by stirring for $5 \mathrm{~min}$ in a mixer with a mass rate of 15:7:3, and then moved into a twin-screw extruder, where the first temperature zone of the twin screw extruder was set at $168{ }^{\circ} \mathrm{C}$, the second temperature zone at $173^{\circ} \mathrm{C}$, the third temperature zone at $178{ }^{\circ} \mathrm{C}$, and the rotating speed at $45 \mathrm{r} / \mathrm{min}$. Subsequently, the E-PP masterbatch was further mixed with $\mathrm{BC}$ in mass rates according to Table 1 and stirred for 10 min to obtain the E-PP/BC mixture, followed by transferring back to the twin-screw extruder and being smelted for $3 \mathrm{~min}$ at the same temperature as the preparation of the E-PP masterbatch, at a rotating speed of $40 \mathrm{r} / \mathrm{min}$. The mixed samples were cut into debris with $10 \mathrm{~mm}$ using scissors and transferred to the mold, followed by pressing into a size of $10 \mathrm{~mm} \times 10 \mathrm{~mm} \times 3 \mathrm{~mm}$. Finally, the above samples were put into the customized mold and pressed at $210{ }^{\circ} \mathrm{C}$ and $10 \mathrm{MPa}$ for $12 \mathrm{~min}$ to obtain the foamed E-PP/BC composites. 
Table 1. The mixing component content of foamed E-PP/BC composites.

\begin{tabular}{cccc}
\hline No. & BC/wt.\% & E-PP/wt.\% & $\begin{array}{c}\text { Foaming Agent and its Auxiliaries/wt.\% } \\
\text { (AC, ZnO, Znst) }\end{array}$ \\
\hline 1 & 0 & 97.5 & 2.5 \\
2 & 5 & 92.5 & 2.5 \\
3 & 20 & 77.5 & 2.5 \\
4 & 30 & 67.5 & 2.5 \\
5 & 40 & 57.5 & 2.5 \\
6 & 50 & 47.5 & 2.5 \\
\hline
\end{tabular}

\subsection{Performance Test}

\subsubsection{Mercury Injection Performance Test}

The pore size and porosity of the foamed E-PP/BC composites were determined using an autopore V 9600 automatic mercury injection device. The samples were placed in the oven at $90^{\circ} \mathrm{C}$ to dry for $4-5 \mathrm{~h}$ before testing. The porosity $(\mathrm{K})$ was calculated according to the following formula: $K=\left(1-\rho_{\mathrm{b}} / \rho_{\mathrm{a}}\right) \times 100 \%$, where $\rho_{\mathrm{b}}$ and $\rho_{\mathrm{a}}$ stand for volume density and apparent density, respectively.

\subsubsection{Density Test}

As a porous material, BC could absorb moisture from air. Therefore, the method for the measurement of the real density of composite materials was conducted by keeping the composite materials in a drying box until they were completely dried, and then moving them into ethanol of $95 \%$ until they reached saturation. The density $(\rho)$ of the composite materials was calculated using the formula $\rho=m c /(m l / \rho l)$, where $m c$ stands for the absolute dry mass, $m l$ for the mass after absorption-saturation, and $\rho l$ for the density after absorption-saturation.

\subsubsection{Formaldehyde Adsorption Performance Test}

The samples were cut into a size of $10 \mathrm{~mm} \times 10 \mathrm{~mm} \times 4 \mathrm{~mm}$. Before testing, the samples were placed in an oven at $80^{\circ} \mathrm{C}$ for $24 \mathrm{~h}$, and the samples were weighed after drying. Subsequently, the samples were put into a formaldehyde adsorption testing desiccator at $26 \pm 2{ }^{\circ} \mathrm{C}$ to test the mass after formaldehyde adsorption for $24 \mathrm{~h}$ until the weight remained unchanged. The formaldehyde adsorption rate of the samples was calculated according to the equation $A J=(m t-m o) / m o \times 100 \%$, where $A J, m o$, and $m t$ stand for formaldehyde adsorption rate, and the mass before and after immersion, respectively.

\subsubsection{Mechanical Properties Test}

According to the Chinese GB/T 9431-2008 standard, an electronic universal testing machine was used to test the static bending strength of the samples. The materials were made into a standard specimen with a size of $80 \mathrm{~mm} \times 10 \mathrm{~mm} \times 4.5 \mathrm{~mm}$. The test span was set at $70 \mathrm{~mm}$, and the tensile rate was $10 \mathrm{~mm} / \mathrm{min}$. The results were estimated based on the formula $\sigma_{1}=3 F L /\left(2 b h^{2}\right)$, where $\sigma_{1}$ stands for bending strength, $F$ for the external force, $L$ for span, $b$ for width of specimen, and $h$ for thickness of specimen.

\subsection{Characterization}

Fourier infrared spectrometer (FTIR, Perkin Elmer, Akron, OH, USA) was used to characterize the chemical structures of the BC, E-PP, and E-PP/BC samples in the wave number range of $400-4000 \mathrm{~cm}^{-1}$ by scanning 32 times. The FTIR samples were prepared by mixing the three kinds of powder with $\mathrm{KBr}$ at a mass rate of 1:100, followed by pressing into a circular wafer. X-ray Diffraction (XRD-6000, Shimadzu, Tokyo, Japan) was used to analyze the crystallinity of the samples with a scanning range of $2^{\circ}-80^{\circ}(2 \theta)$ and scanning speed of $2^{\circ} / \mathrm{min}$, and the operating voltage was set at $40 \mathrm{KV}$, the tube current at $30 \mathrm{~mA}$, and the wavelength at $0.15406 \mathrm{~nm}$. Scanning electron microscopy (SEM, Hitachi SU 8010, Tokyo, Japan) was used to observe surface morphologies of different samples at the emission 
voltage of $15 \mathrm{KV}$. The composites were soaked in liquid nitrogen for $30 \mathrm{~s}$ to quench, and then the quenched composites were cut into a thickness of $2 \mathrm{~mm}$ and sprayed with gold to get the SEM samples.

\section{Conclusions}

Foamed EVA-modified PP/BC composites were successfully prepared with up to $50 \%$ of $\mathrm{BC}$ as replacement for PP. The BC content dictates the properties of the foamed E-PP/BC composites. At a low BC content ( $5 \mathrm{wt} . \%)$, the foamed E-PP/BC composites exhibit no obvious change in their pore size, density, formaldehyde adsorption, or bending strength. However, with increasing content of BC, the foamed E-PP/BC composites exhibit a significant improvement in density and formaldehyde adsorption, but a steady decrease in the bending strength. With all factors considered, the foamed E-PP/BC (40 wt.\%) composite achieved the optimal performance, with a density of $0.90 \mathrm{~g} / \mathrm{cm}^{3}, 24-\mathrm{h}$ formaldehyde adsorption rate of 0.48 , and bending strength of $11.59 \mathrm{MPa}$. Low density, and good strength and adsorptive properties make the foamed E-PP/BC composites suitable for many interior paneling applications.

Author Contributions: Data curation, W.L., J.H., J.Z. and Y.S.; Formal analysis, J.Z.; Funding acquisition, W.Z.; Investigation, Y.S., W.L., J.H., J.Z. and W.Z.; Methodology, W.Z. and C.D.; Writing -review \& editing, J.H. and C.D. All authors have read and agreed to the published version of the manuscript.

Funding: This work was supported by the Science and Technology Planning Project of Zhejiang Province (No. 2018C02008), Natural Science Foundation of Zhejiang Province (No. LY21C160002), Scientific Research Development Foundation of Zhejiang A\&F University (No. 2018FR054).

Institutional Review Board Statement: Not applicable.

Informed Consent Statement: Not applicable.

Data Availability Statement: The data presented in this study are available on request from the corresponding author.

Acknowledgments: The authors would like to thank national engineering and technology research center of wood-based resources provision and comprehensive use of an experimental platform in this experiment.

Conflicts of Interest: We declare that we do not have any commercial or associative interests that represent a conflict of interest in connection with the work submitted.

\section{References}

1. Siddique, R.; Khatib, J.; Kaur, I. Use of recycled plastic in concrete: A review. Waste Manag. 2008, 28, 1835-1852. [CrossRef]

2. Cui, Y.; Lee, S.; Noruziaan, B.; Cheung, M.S.; Tao, J. Fabrication and interfacial modification of wood/recycled plastic composite materials. Compos. Part A Appl. Sci. Manuf. 2008, 39, 655-661. [CrossRef]

3. Ito, Y.; Hasuda, H.; Sakuragi, M. Surface modification of plastic, glass and titanium by photoimmobilization of polyeth-ylene glycol for antibiofouling. Acta Biomater. 2007, 3, 1024-1032. [CrossRef] [PubMed]

4. Gerngross, T.U.; Slater, S.C. How Green are Green Plastics? Sci. Am. 2000, 283, 36-41. [CrossRef]

5. Moore, C.J. How much plastic is in the ocean? You tell me! Mar. Pollut. Bull. 2015, 92, 1-3. [CrossRef] [PubMed]

6. Nolte, T.M.; Hartmann, N.B.; Kleijn, J.M.; Garnæs, J.; van de Meent, D.; Hendriks, A.J.; Baun, A. The toxicity of plastic nanoparticles to green algae as influenced by surface modification, medium hardness and cellular adsorption. Aquat. Toxicol. 2017, 183, 11-20. [CrossRef]

7. Khosravani, M.R. Composite Materials Manufacturing Processes. Appl. Mech. Mater. 2011, 110-116, 1361-1367. [CrossRef]

8. Senthil, S.; Raguraman, M.; Thamarai Manalan, D. Manufacturing processes \& recent applications of aluminium metal ma-trix composite materials: A review. Mater. Today Proc. 2020. [CrossRef]

9. Diaz-Quijada, G.A.; Peytavi, R.; Nantel, A.; Roy, E.; Bergeron, M.G.; Dumoulin, M.M.; Veres, T. Surface modification of thermoplastics-Towards the plastic biochip for high throughput screening devices. Lab Chip 2007, 7, 856-862. [CrossRef]

10. Fabiyi, J.S.; McDonald, A.G.; Mcllroy, D. Wood modification effects on weathering of HDPE-based wood plastic compo-sites. J. Polym. Environ. 2009, 17, 34-48. [CrossRef]

11. Stamboulis, A.; Baillie, C.A.; Garkhail, S.K.; Van Melick, H.G.H.; Peijs, T. Environmental durability of flax fibres and their Composites based on Polypropylene Matrix. Appl. Compos. Mater. 2000, 7, 273-294. [CrossRef] 
12. Lertwimolnun, W.; Vergnes, B. Influence of compatibilizer and processing conditions on the dispersion of nanoclay in a polypropylene matrix. Polymer 2005, 46, 3462-3471. [CrossRef]

13. García-García, D.; Carbonell, A.; Samper, M.; García-Sanoguera, D.; Balart, R. Green composites based on polypropylene matrix and hydrophobized spend coffee ground (SCG) powder. Compos. Part B Eng. 2015, 78, 256-265. [CrossRef]

14. Mohebbi, A.; Mighri, F.; Ajji, A.; Rodrigue, D. Current issues and challenges in polypropylene foaming: A review. Cell. Polym. 2015, 34, 299-338. [CrossRef]

15. Hou, J.; Zhao, G.; Zhang, L.; Wang, G.; Li, B. High-expansion polypropylene foam prepared in non-crystalline state and oil adsorption performance of open-cell foam. J. Colloid Interface Sci. 2019, 542, 233-242. [CrossRef] [PubMed]

16. Antunes, M.; Mudarra, M.; Velasco, J.I. Broad-band electrical conductivity of carbon nanofibre-reinforced polypropylene foams Carbon 2011, 49, 708-717. [CrossRef]

17. Xu, Z.-M.; Jiang, X.-L.; Liu, T.; Hu, G.-H.; Zhao, L.; Zhu, Z.-N.; Yuan, W.-K. Foaming of polypropylene with supercritical carbon dioxide. J. Supercrit. Fluids 2007, 41, 299-310. [CrossRef]

18. Ding, J.; Ma, W.; Song, F.; Zhong, Q. Effect of nano-calcium carbonate on microcellular foaming of polypropylene. J. Mater. Sci. 2012, 48, 2504-2511. [CrossRef]

19. Gong, W.; Fu, H.; Zhang, C.; Ban, D.; Yin, X.; He, Y.; He, L.; Pei, X. Study on foaming quality and impact property of foamed polypropylene composites. Polymer 2018, 10, 1375. [CrossRef]

20. Fu, D.; Chen, F.; Kuang, T.; Li, D.; Peng, X.; Chiu, D.Y.; Lin, C.S.; Lee, L.J. Supercritical $\mathrm{CO}_{2}$ foaming of pressure-induced-flow processed linear polypropylene. Mater. Des. 2016, 93, 509-513. [CrossRef]

21. Qiao, J.C.; Pelletier, J.M.; Kou, H.C.; Zhou, X. Modification of atomic mobility in a Ti-based bulk metallic glass by plastic de-formation or thermal annealing. Intermetallics 2012, 28, 128-137. [CrossRef]

22. Farsi, M. Wood-plastic composites: Influence of wood flour chemical modification on the mechanical performance. J. Reinf. Plast. Compos. 2010, 29, 3587-3592. [CrossRef]

23. Sohn, J.S.; Cha, S.W. Effect of chemical modification on mechanical properties of wood-plastic composite injection-molded parts. Polymer 2018, 10, 1391. [CrossRef]

24. Sun, J.; Sun, Y.; Yang, Y.; Tong, X.; Liu, W. Plastic/rubber waste-templated carbide slag pellets for regenerable $\mathrm{CO}_{2}$ capture at elevated temperature. Appl. Energy 2019, 242, 919-930. [CrossRef]

25. Chan, T.; Mackie, K.R. Flexural strengthening of reinforced concrete beams using externally bonded polyurethane carbon fiber-reinforced polymer composite systems. ACI Struct. J. 2020, 117, 311-324. [CrossRef]

26. Asada, T.; Ishihara, S.; Yamane, T.; Toba, A.; Yamada, A.; Oikawa, K. Science of bamboo charcoal: Study on carbonizing temperature of bamboo charcoal and removal capability of harmful gases. J. Health Sci. 2002, 48, 473-479. [CrossRef]

27. Wang, S.-Y.; Tsai, M.-H.; Lo, S.-F. Effects of manufacturing conditions on the adsorption capacity of heavy metal ions by Makino bamboo charcoal. Bioresour. Technol. 2008, 99, 7027-7033. [CrossRef] [PubMed]

28. Suresh, S.; Bandosz, T.J. Removal of formaldehyde on carbon-based materials: A review of the recent approaches and findings. Carbon 2018, 137, 207-221. [CrossRef]

29. Carter, E.M.; Katz, L.E.; Speitel, G.E.; Ramirez, D. Gas-phase formaldehyde adsorption isotherm studies on activated carbon: Correlations of adsorption capacity to surface functional group density. Environ. Sci. Technol. 2011, 45, 6498-6503. [CrossRef]

30. Rengga, W.D.P.; Sudibandriyo, M.; Nasikin, M. Development of formaldehyde adsorption using modified activated carbon-A review. Int. J. Renew. Energy Dev. 2012, 1, 75-80. [CrossRef]

31. He, G.; Feng, M.; Dai, C. Development of soy-based adhesives for the manufacture of wood composite products. Holzforschung 2012, 66, 857-862. [CrossRef]

32. Li, S.; Wang, H.; Chen, C.; Li, X.; Deng, Q.; Gong, M.; Li, D. Size effect of charcoal particles on the properties of bamboo charcoal/ultra-high molecular weight polyethylene composites. J. Appl. Polym. Sci. 2017, 134, 45530. [CrossRef]

33. Zhang, H.; Yao, W.; Qian, S.; Shen, K. Fabrication and reinforcement of ternary composites based on polypropylene matrix with bamboo particle/ultrafine bamboo-char. Polym. Compos. 2018, 39, 4364-4371. [CrossRef]

34. Zhang, S.; Yao, W.; Zhang, H.; Shen, K. Polypropylene biocomposites reinforced with bamboo particles and ultrafine bamboo-char: The effect of blending ratio. Polym. Compos. 2018, 39, 640-646. [CrossRef]

35. Zhang, J. Preparation and Characterization of Bamboo Charcoal/Polypropylene Composite Foaming Materials. Master's Thesis, Zhejiang A \& F University, Hangzhou, China, 2021.

36. Reyes-Labarta, J.A.; Marcilla, A. Thermal treatment and degradation of cross-linked ethylene vinyl acetate-polyethyleneazodicarbonamide-ZnO foams. Complete kinetic modeling and analysis. Ind. Eng. Chem. Res. 2012, 51, 9515-9530. [CrossRef]

37. Wang, R.; Amano, Y.; Machida, M. Surface properties and water vapor adsorption-desorption characteristics of bamboo-based activated carbon. J. Anal. Appl. Pyrolysis 2013, 104, 667-674. [CrossRef] 